\title{
SUSPENSION OF PAYMENTS, BANK FAILURES, AND The Nonbank PUblic's LoSSES*
}

\author{
Gerald P. Dwyer, Jr. \\ Federal Reserve Bank of Atlanta \\ Iftekhar Hasan \\ Rensselaer Polytechnic Institute \\ Bank of Finland
}

March 2003

\begin{abstract}
Suspensions of payments are an important part of many explanations of the rise of the Federal Reserve, theories of banking panics and even counter-factual evaluations of the Great Depression. To date though, there is no evidence on suspensions' effects. We present evidence about suspensions of payments from an episode that is close to a controlled experiment for examining their effects. In 1861, about 44 percent of the banks in Wisconsin closed, 87 percent of the banks in Illinois closed, and noteholders suffered substantial losses. The historical record suggests that an effective suspension of payments in Wisconsin but not in Illinois may be the explanation. Historical and statistical evidence indicate that the suspension of payments decreased the number of banks that closed as well as noteholders' losses. Our statistical evidence indicates a 20 percent increase in the probability that an average bank in the two states remains open with the suspension of payments. The suspension of payments decreases noteholders' losses by about 15 cents per dollar of notes.

* We thank George Benston, Robert Bliss, William Dougan, Kevin Dowd, Andrew Economopoulos, Larry Neal, William Roberds, Raymond Sauer, Anna Schwartz, George Selgin, Warren Weber, and Eugene White for helpful comments. We also received helpful comments from participants in seminars at the Atlanta Finance Workshop, Clemson University, the Federal Reserve Banks of Atlanta, Dallas, and Minneapolis, Colorado State University, Montana State University, Texas A\&M University, the University of Arizona, the University of Siena, the University of Texas, the University of Wyoming, and sessions at the Cliometrics Society, Financial Management Association and a Midwest Macroeconomics meeting. Andrew Economopoulos and Warren Weber provided data and helped interpret them. Erin O'Hara obtained copies of the state laws. Dwyer thanks the Federal Reserve Banks of Atlanta and Minneapolis and Hasan thanks the Federal Reserve Bank of Atlanta and the Bank of Finland for hospitable environments for completing parts of this paper. The views expressed here are ours and not necessarily those of the Federal Reserve Bank of Atlanta, the Federal Reserve System or the Bank of Finland. Any remaining errors are our responsibility.
\end{abstract}




\title{
SUSPENSION OF PAYMENTS, BANK FAILURES, AND THE NONBanK Public's LosSes
}

\author{
March 2003
}

\begin{abstract}
Suspensions of payments are an important part of many explanations of the rise of the Federal Reserve, theories of banking panics and even counter-factual evaluations of the Great Depression. To date though, there is no evidence on suspensions' effects. We present evidence about suspensions of payments from an episode that is close to a controlled experiment for examining their effects. In 1861, about 44 percent of the banks in Wisconsin closed, 87 percent of the banks in Illinois closed, and noteholders suffered substantial losses. The historical record suggests that an effective suspension of payments in Wisconsin but not in Illinois may be the explanation. Historical and statistical evidence indicate that the suspension of payments decreased the number of banks that closed as well as noteholders' losses. Our statistical evidence indicates a 20 percent increase in the probability that an average bank in the two states remains open with the suspension of payments. The suspension of payments decreases noteholders' losses by about 15 cents per dollar of notes.
\end{abstract}




\section{INTRODUCTION}

Suspensions of payments by banks have a bad reputation. Arguably, eliminating suspensions of payments, periods when banks jointly refuse to convert their liabilities into outside money or other assets, was an important impetus for creating the Federal Reserve (Gorton and Winton 2002). Such suspensions of payments were repeated events during the National Banking period from 1863 to 1914, but it is hard to disentangle the suspensions' effects from other factors' effects. Indeed, while clearly indicating that such suspensions were not cures for banking panics, Friedman and Schwartz (1963, pp. 167-68, 311-12, 329-30, 693-94) suggest that just such a suspension in 1930 would have stopped a scramble for liquidity by banks that lowered the value of the banks' securities, resulted in additional failures and increased the severity of the Great Depression. Calomiris and Mason (1997) find that bank failures in Chicago in the June 1932 panic reflected the weakness of the banks in the face of a common shock to their asset values, although cooperation among the banks helped to prevent other banks from closing. Bernanke (1983) presents evidence that these bank failures contributed to the severity of the Depression but does not address the issue of whether a suspension would have affected the number of banks closing.

Wallace (1990), Selgin (1993) and Gorton and Huang (2002) suggest that suspensions of payments may well be optimal in a banking system with many banks. Banks promise to pay the par value of their obligations on demand, a promise that cannot be honored in all states of the world. The resolution of that contractual obligation in circumstances when many banks cannot honor it, in particular banking panics, affects evaluations of the costs and benefits of that contract and the costs and benefits of central banking. It is possible that a suspension of payment is merely a device to lower the transition costs to a new equilibrium after a banking panic and all bank failures are due 
to insolvency even without a run. It also is possible that a suspension of payments mitigates the effects of a banking panic and affects the equilibrium after the panic and suspension.

An episode 70 years before the Depression provides close to a controlled experiment to uncover the effects of suspensions of payments and assess Friedman and Schwartz's conjecture. In 1861, about 44 percent of the banks in Wisconsin closed and 87 percent of the banks in Illinois closed. The problems for banks in Illinois and Wisconsin were associated with falling prices of southern and border state bonds that they held. ${ }^{1}$ Much has been written about why so many banks closed, but the disparity in the number of banks closing in the two states has been ignored. Forty-four percent of banks closing is large by any standard, let alone 87 percent, but a difference between 44 and 87 percent of banks closing also is rather large. Generally speaking, the banking systems in the two states were quite similar and the responses to the decreases in bond prices also were similar. There is at least one major difference, though, between Illinois and Wisconsin: an effective suspension of payments in Wisconsin but not Illinois.

In this paper, we examine the effects of a suspension of payments by comparing Illinois and Wisconsin in this episode. In the next section, we discuss the banking laws in Illinois and Wisconsin and the events of 1861. In the succeeding section, we discuss the responses by bankers, banking regulators and legislators to these events. We then present a statistical analysis to estimate the effects on the number of banks closing and noteholders' losses. We conclude that the suspension of

\footnotetext{
${ }^{1}$ In an earlier paper, we (Hasan and Dwyer 1994) show that free bank failures concentrated in short periods generally were precipitated by episodic events, with an implication that falling bond prices are not a general explanation for these failures. Nonetheless, dramatic decreases in bond prices are associated with the large number of banks closing in Illinois and Wisconsin at the start of the Civil War (Rolnick and Weber 1984; Economopolous 1988; Hasan and Dwyer 1994; and the earlier work referenced in these papers).
} 
payments decreased the probability of a bank failing by 20 percentage points and reduced noteholders' losses by 15 cents per dollar of notes, differences that are statistically and economically significant.

\section{THE BANKING SYSTEMS AND 1861}

The similarities between the banking laws in Illinois and Wisconsin in this period are more striking than the differences. There are important differences between the balance sheets of the banks, though.

\section{Background}

The laws in the two states were broadly similar. Free banking began in both states in 1852 . Table 1 summarizes the major provisions of the free banking laws in force in both states in late 1860 and early 1861.

In both states, a minimum amount of subscribed capital was necessary in order to start a bank. The banks' shareholders were subject to double liability: if the bank became insolvent, each shareholder was liable for an amount equal to his subscribed capital in addition to the subscribed capital itself. In 1857 , the Illinois legislature amended the law to require that at least $\$ 50,000$ of capital actually be paid in. ${ }^{2}$ In addition, Wisconsin required that stockholders post personal bonds for one quarter of the amount of notes outstanding. Before 1860, these guarantees were sufficiently large to cover all losses that otherwise would have been borne by holders of Wisconsin banknotes.

\footnotetext{
${ }^{2}$ While $\$ 50,000$ of paid-in capital is more restrictive than Wisconsin's requirement of $\$ 25,000$ of subscribed capital, the force of the Illinois law was negated by an Illinois Supreme Court decision. Wisconsin required that a bank's notes not exceed its subscribed capital. The significance that should be attached to these provisions is suggested by changes in the laws after the fall in bond prices in 1861: both Illinois and Wisconsin limited notes to three times paid-in capital.
} 
Both states accepted interest paying state and federal government bonds as collateral for banknotes. The amount of notes that could be issued was based on the market value of the bonds in New York City in the preceding six months. In Illinois, notes could be issued for as much as 90 percent of the average market value of the bonds; in Wisconsin, notes could be issued for as much as 100 percent of the average market value of the bonds. In no case could the amount of notes issued exceed the par value of the bonds or their market value at the time of deposit with the banking authority. Hence, the laws did not permit deposit of bonds with market prices below par and issuance of notes at par value, the major impetus to wildcat banking suggested by Rockoff (1975). Before the onset of the Civil War, bonds' coupon rates were such that 6 percent coupon bonds generally sold for prices above par value. This requirement that bonds be valued at the lesser of par or market arguably contributed to banks' preference for bonds trading near par, such as southern bonds or Missouri bonds, rather than bonds trading at premiums as high as 14 percent, such as United States and northern states' bonds.

Banks in both states were penalized for failing to convert notes into specie at par on demand. If a bank failed to redeem its notes at par on demand, a noteholder could formally protest to the banking authority. If the bank redeemed the notes during a grace period, the noteholder was compensated. In Illinois, a bank was required to pay 12 percent interest on protested notes; in Wisconsin, a bank was required to pay "five percent damages" on protested notes. In both Illinois and Wisconsin, if a bank did not redeem the protested notes within the grace period of ten days after receiving notice, the banking authority would sell all of the bank's deposited bonds and give 
noteholders the lesser of the proceeds or the par value. ${ }^{3}$ In Wisconsin, the Comptroller would collect on the personal bonds posted by the stockholders if the deposited bonds were inadequate to redeem the notes at par. If the amount paid by the banking authority was less than the par value of the notes, the noteholders could file suit against the bank and its stockholders. ${ }^{4}$

Both states also required that banks submit periodic reports. Illinois law required each bank to submit a quarterly report on its assets and liabilities. These reports were then published in local and state newspapers, thereby providing some indication to noteholders about banks' assets and liabilities. In Wisconsin, such reports were submitted and published semi-annually.

Table 2 shows the aggregate balance sheets of the banks in Illinois and Wisconsin close to the turn of the year from 1860 to 1861 . These aggregate balance sheets reveal total assets and liabilities about 15 percent greater in Illinois than in Wisconsin banks. Notes as a fraction of liabilities are much more important than in Wisconsin. Notes outstanding are almost 57 percent of liabilities in Illinois and only 25 percent of liabilities in Wisconsin. Deposits are much more important in Wisconsin. Deposits are only four percent of liabilities in Illinois and are almost 25 percent of liabilities in Wisconsin. Despite having detailed provisions concerning redemption of notes, the laws of the two states were silent about deposits.

Table 3 summarizes changes in the number of free banks in Illinois and Wisconsin. Among banks closing, the table distinguishes between banks that redeemed their notes at par and those that did not. We define ceasing operations as a bank closing and redeeming its banknotes at par; we

\footnotetext{
${ }^{3}$ This time limit is the difference between these rules, the option clauses in Scotland from 1730 to 1765 and Dowd's (1988) suggestion that such clauses could be a remedy for banking panics.

${ }^{4}$ Neither the laws of Illinois or Wisconsin specifically mention deposits. It is possible that banks were legally free to contract with depositors under any terms that they desired.
} 
define failing as a bank closing and redeeming its notes at less than par. The number of free banks in Wisconsin increased gradually up to 1860 . The number of free banks in Illinois increased more quickly at the start of free banking, stayed on a plateau from 1857 to 1859 and then increased substantially from 1859 to 1861 . Consistent with the greater increase in the number of banks in Illinois in the years just before 1861, banknotes increased relatively more in Illinois than in Wisconsin in those years. From January 1858 to January 1860, the value of Illinois banknotes increased about 75 percent, from $\$ 5.2$ million to $\$ 9.0$ million, while the value of Wisconsin notes increased about 50 percent, from $\$ 2.9$ million to $\$ 4.4$ million. $^{5}$

Before 1861 , losses borne by holders of Illinois and Wisconsin banknotes were relatively small. Of the two banks that failed in Illinois before 1861, noteholders in these banks received 94 and 88 cents on the dollar. Before 1860, no holder of a note issued by a Wisconsin free bank had any loss; in 1860, one free bank failed and noteholders received 96 cents on the dollar.

Runs on the Banking Systems in 1861

The distribution over time of banks closing and failing is far from uniform. The year 1861 stands out, with 87 percent of the banks in Illinois and 44 percent of the banks in Wisconsin closing. Of the 83 banks that closed in Illinois, 80 failed. Of the 47 banks that closed in Wisconsin, 35 failed. Every study of which we are aware indicates that declining prices of southern and border state bonds were an important reason for the bank failures in 1861. The decreases in the number of banks are associated with substantial decreases in notes outstanding. From January 1860 to January 1862,

${ }^{5}$ The sources of these and other data in the paper are provided in a Data Appendix on request. 
notes issued by Illinois banks fell from $\$ 9.0$ million to $\$ 1.4$ million and notes issued by Wisconsin banks fell from $\$ 4.3$ million to $\$ 1.4$ million. $^{6}$

We define a banking panic as a decrease in demand for a banking system's liabilities associated with an increase in liability holders' estimated probability that the banks will temporarily or permanently fail to redeem their liabilities at par. The decrease in notes issued and the closing of many banks in 1861 suggest that there might have been a panic, but they are not compelling by themselves. Discount rates on banknotes, final redemption rates and the losses suffered by the banks provide evidence that is persuasive to us that there were runs on both states' banking systems.

We summarize discount rates on banknotes in combination with redemption rates in Table 4. The data in Table 4 are for banks that were in existence in October 1860 in Illinois and January 1861 in Wisconsin. The table provides a complete accounting of the observed discount rates. If the bank still was operating in January 1862 , the redemption rate is par, one dollar. Otherwise, the redemption rate is the final dollar amount received by noteholders. We summarize the distribution of redemption rates by providing, in effect, a discrete probability distribution function or histogram for the loss rate on notes, one minus the redemption rate. For each discount rate, the column labeled "noteholders' loss rate" indicates the number of banks in which noteholders had a loss rate larger than in the row above and not more than the row label. For example, in Illinois, holders of 3 banks' notes had loss rates more than 5 percent but not more than 10 percent. In January 1860, the discount rates on banknotes for banks in both Illinois and Wisconsin are 3 percent. While it might seem

\footnotetext{
${ }^{6}$ Banknotes issued by Illinois banks increased from $\$ 9.0$ million in January 1860 to $\$ 11.0$ million in October 1860, before falling dramatically. After January 1862, banknotes in Illinois fell from $\$ 1.4$ million to $\$ 0.6$ million in January 1863 . Banknotes issued by Wisconsin banks increased from $\$ 1.4$ million to $\$ 1.6$ million in July 1862.
} 
surprising that all of the discount rates are the same, this situation was typical and an equilibrium (Gorton 1996). ${ }^{7}$ In June 1860, the median and modal discount rates are 2.25 percent with a little dispersion. In January 1861, the discount rates for all banks in Wisconsin are 12 percent while there is diffusion for banks in Illinois with a mode of 12 percent. In June 1861 in Wisconsin, 67 banks have a discount rate of 20 percent and 43 banks have a discount rate of 60 percent. At the same time, the discount rate for all banks in Illinois is the higher of the two rates for banks in Wisconsin: 60 percent. By January 1862, the distributions are yet more diffuse.

Over time, the discount rates become better predictors of the redemption rates. For Illinois, the simple correlation of the discount rates with the final loss rate to noteholders increases from 0.16 in June 1860 to 0.86 in January 1862. In Wisconsin for the same period, the correlation increases from 0.06 to 0.83 . By January 1862 , the discount rates are closely related to the final loss rates borne by noteholders. Even by January 1862, though, the discount rates on notes are high relative to noteholders' eventual loss rates on the notes. The average final loss rate is 19.7 percentage points less than the average discount rate in January 1862 for Illinois banks and 12.6 percentage points less for Wisconsin banks. The standard deviations of these mean differences are 0.97 and 1.37 percentage points, respectively. These magnitudes suggest two things. First, it is quite unlikely that the discount rates reflect only the usual discount rate for interest and transportation costs. Second, it is quite unlikely that the discount rates are higher by the same amounts in both states. Instead, the discount rates are higher relative to loss rates in Illinois than in Wisconsin.

\footnotetext{
${ }^{7}$ The existence of balance sheet information after January 1860 is the criterion for inclusion. Hence, the discount rates would be expected to be more diffuse over time if banks' experience differed. The distribution of discount rates for all banks with any discount rate from January 1860 to January 1862 , which includes banks for which balance sheet information is not available and possibly some private banks, is little different.
} 
Figure 1 shows prices of bonds that are more than 10 percent of the aggregate portfolio of banks in either state in 1861 ; it also shows United States bond prices for comparison. ${ }^{8}$ All of these bonds have 6 percent coupon rates. With the exception of the Illinois bonds, the figure shows a fairly complete record for these bonds. ${ }^{9}$ The prices of southern and border state bonds fell before the Civil War and fell dramatically the same week that the Confederates fired on Fort Sumter and Lincoln responded by ordering a blockade and calling up troops. ${ }^{10}$ The low prices occur in June 1861 and bond prices increase thereafter to the end of 1862 .

Friedman and Schwartz (1963) suggest that the banking panics from 1930 to 1933 were associated with falling asset prices in part because banks were liquidating assets in response to the banking panics. While it is not necessary for our basic point and it would take us too far afield to examine the issue in detail in this paper, Figure 1 is suggestive of such an effect in 1861 . The rise in bond prices after June 1861 came despite legislative actions that were severe by contemporary standards and would make the decline more severe if unanticipated (Schwab 1901, especially Chapters VI and XIII). Both the Federal and the Confederate government passed laws confiscating assets of residents of the other jurisdiction. In addition, the Confederate government passed a law

\footnotetext{
${ }^{8}$ Movements of northern states' bond prices generally are similar to movements of United States bond prices (Dwyer, Hafer and Weber 1999).

${ }^{9}$ Only fragmentary data on Illinois bonds prices are available in Bankers' Magazine, the source of our bond prices. We see no evidence of changes in bond prices specific to Illinois in Figure 1, although nontrivial transitory changes could be concealed by the paucity of observations. There is no evidence, though, of events other than the bank failures that might have affected prices of Illinois bonds.

${ }^{10}$ It is less surprising that Missouri bonds fell as much as southern bonds when one recalls that Missouri was under martial law with a provisional state government for the duration of the war (Brownlee 1958). Ratchford (1941, pp. 124-25) indicates that Missouri paid no interest on its bonds from the outbreak of the Civil War until the ratification of a Reconstruction-era constitution in 1866.
} 
requiring citizens of the Confederacy to pay into the Confederate Treasury any funds due to northerners. (Predictably, little revenue was collected.) Some states stopped coupon payments to northerners in the middle of 1861 and several states were in arrears by the middle of 1862 . Despite all of this, prices of the southern bonds increased after Summer 1861. While there may be other explanations, this pattern of lower bond prices when banks are liquidating their portfolios and increases thereafter is consistent with banks' liquidation of their portfolios lowering the observed prices. $^{11}$

Bonds held by banks in both states are broadly similar. Table 5 shows the distribution of banks' bond holdings in Fall 1860. In the aggregate, Illinois banks have 68 percent of their notes backed by depreciating southern and border state bonds and Wisconsin banks have 66 percent backed by such bonds. There are substantial losses on these portfolios. We estimate that the aggregate loss on these portfolios due to the change in bond prices from June 1860 to June 1861 is 43.7 cents per dollar of notes in Illinois and 43.1 cents per dollar on notes in Wisconsin.

Even though these estimated losses relative to notes are quite similar in the two states, losses relative to stockholders' subscribed capital are quite different: 70.9 percent in Illinois; and 27.2 percent in Wisconsin. Figure 2 shows the distributions of losses relative to capital at the end of 1860 for banks in Illinois and Wisconsin. The horizontal axis in the figure is the ratio of losses relative to capital and the vertical axis indicates whether a bank failed, ceased operations, or remained open. A vertical line is drawn for each bank at the appropriate point on the vertical axis and at the estimated value of losses relative to capital. The most striking aspect of Figure 2 is the higher losses

\footnotetext{
${ }^{11}$ This outcome is similar to the fall in Indiana state bond prices in 1854 due to a decrease in banks' demand for those bonds (Hasan and Dwyer 1994) and consistent with at least one very preliminary characterization of asset markets (Aiyargari and Gertler 1999).
} 
relative to capital in Illinois than in Wisconsin. In Illinois, the mean and median losses relative to capital are 0.806 and 0.595 ; in Wisconsin, the mean and median losses are 0.335 and 0.360 . As is apparent from the figure, banks in Illinois had far higher losses relative to capital. The distributions within Illinois and Wisconsin indicate that failed banks have higher losses relative to capital than banks that remained open, supporting the evidence of its importance across states.

The higher ratio of losses to capital in Illinois than in Wisconsin is associated with Illinois banks' greater leverage. The ratio of notes to capital is much higher in Illinois than in Wisconsin. The mean and median ratios of notes to capital, respectively, are 1.95 and 1.37 in Illinois and 0.78 and 0.93 in Wisconsin. About 75 percent of banks in Illinois have notes greater than their subscribed capital, a condition that is illegal in Wisconsin. In sum, banks in Illinois are more highly leveraged than banks in Wisconsin and have higher losses relative to capital. This suggests that greater leverage and consequent higher losses relative to capital may be at least part of the explanation why more banks closed in Illinois than in Wisconsin, a possibility that we examine in the statistical analysis below.

\section{RESPONSES IN ILLINOIS AND WISCONSIN}

How did bankers, banking regulators and legislators respond to falling bond prices and their implications for banks in Illinois and Wisconsin? Common threads in both states are: calls on banks to increase their deposited bonds or decrease their notes when the backing for their notes fell in value; legislation; and bankers' attempts to jointly certify each others' notes. 
Illinois

In November 1860, the Illinois Bank Commissioners responded to falling bond prices by calling on twenty-two banks to increase their bond deposits or decrease their note issue. ${ }^{12}$ Shortly after the call, the Bank Commissioners extended the deadline for replenishing the bond deposit from forty days to four months. By the beginning of 1861, the bond accounts of most banks fell short of their notes' value. In January 1861, thirty-seven banks attempted to jointly guarantee each other's notes, but this attempt was unsuccessful.

In February 1861, the Illinois legislature amended the state banking law. Most importantly for our purposes, the legislature attempted to restrict, for six months, liquidations associated with protested notes. If, by April 1861, a bank's bond account fully backed its outstanding notes, then the bank need not be liquidated for failure to redeem its note at par. This privilege would extend through August 1861 if a bank made up any deficiency continuing for ten days by the end of a succeeding ten day grace period. In effect, if a bank had a bond account that fully backed its notes by April 1861, it could suspend payments.

This change in the law in February 1861 proved to be pointless, however. Bond prices fell much further over the next 2 months. In addition, the law shortened banks' grace period for adjusting their bond accounts from forty days to ten days. The governor of Illinois indicated the practical effect of this law in his annual message to the legislature in January, 1863:

\footnotetext{
12 This account is based on Dowrie (1913, Ch. V), James (1938, vol. I, Ch. IX), Illinois Journal of the House of Representatives (1861), and Laws of Illinois (1861.)
} 
Whenever the securities of any bank ... fell below the amount required by law, the auditor gave the necessary notice, requiring the owner to make up the deficiency; and failing to do this, it was at once placed into liquidation, and the assets sold. (Quoted in Secretary of the Treasury's report on The Condition of the Banks in the United States, House Executive Document no. 20, 38th Congress, 1st Session, p. 161.)

By March 1861, when the grace period for the November call was up, seventeen of the twenty-two banks subject to the November call did not adjust their bond accounts with the Auditor and were placed in liquidation. In addition, in early April 1861, bankers in Chicago refused to accept the notes of an additional thirty-two banks and the Chicago Tribune reported that as many more banks were likely to have problems.

Interestingly, some Illinois banks suspended payments in the troubled year of 1854 and the Auditor did not liquidate banks solely for this reason. Such tolerance of a suspension of payments was not to be in 1861. Possibly the ill-fated February law made it more difficult for the Auditor to look the other way instead of liquidating banks with protested notes.

\section{Wisconsin}

While calls for deposits of additional bonds, legislation, and bankers' attempts to jointly certify each others' notes also occur in Wisconsin, a major difference between Illinois and Wisconsin is an effective suspension of payments in Wisconsin. In October and November 1860, and in early February 1861, the Wisconsin Comptroller of Banking ordered banks to adjust their bond accounts or notes to offset the depreciation of the bonds. ${ }^{13}$ In February 1861, the state legislature postponed until April the third call for adjustment. The end of the postponement in early April was quickly followed by an announcement by Chicago bankers that they would not accept the

\footnotetext{
${ }^{13}$ This account is based on Merk (1916, Ch. VII), Krueger (1933, Ch. IV), Andersen (1954, Ch. II), Current (1976, Ch. 9) and Laws of Wisconsin (1861.)
} 
notes of forty of the 107 Wisconsin banks. The next day, a meeting of Wisconsin bankers produced a declaration that Wisconsin bankers would not accept the notes of nineteen banks until the banks brought the backing for their notes up to 95 percent of the value of their notes.

On April 17, the legislature passed a law that made it possible for banks to suspend payments. The law stopped, until December, notary publics from notarizing protests of banknotes and the Comptroller of Banking from redeeming protested notes. This law suspended the requirement that banks convert notes into specie at par in the same week that bond prices fell dramatically.

A second bankers' meeting was held on April 25 at which the bankers declared that they would not accept the notes of eighteen more banks. At this meeting, the bankers also declared they would accept the notes of all other Wisconsin banks at par until December 1, 1861. As it turned out, the banks did not keep this commitment to take all other banks' notes at par. On June 3, the Comptroller of Banking made an additional call on banks to adjust their bond accounts or notes. Eighteen of the banks with notes accepted at par by other banks failed to adjust their bond accounts. On June 21, Milwaukee bankers met and refused to accept at par the notes of ten of these banks.

In preparation for resumption in December, the Wisconsin Bankers Association created a committee to acquire notes of banks unlikely to be able to resume specie payments and gave the committee the power to levy charges against banks in the association. The committee acquired these notes in exchange for certificates of deposit paying 7 percent interest. While this joint action is interesting, we do not know the magnitude of these operations.

Besides allowing a suspension of payments, the state of Wisconsin issued $\$ 800,000$ of bonds in Summer 1861 to finance part of its war effort and these bonds were purchased by Wisconsin free 
banks. The terms of the purchase were below par. This is not surprising: the bonds' coupon rate was 6 percent per year and the market prices of United States and other northern states' bonds with coupons of 6 percent per year were below par. The banks paid 70 percent of the par value immediately. Sixty percent of this payment was in coin or New York banknotes, and as much as 10 percent could be in current Wisconsin banknotes. The remaining 30 percent was to be paid over the next 15 years from the bonds' semiannual coupon payments. There is no evidence that the bonds were non-price rationed. We estimate that the yield on Wisconsin's bonds is somewhat higher than the yield on Ohio bonds in the last half of 1861 and lower than the yield on United States bonds.

One provision of the bonds made them more advantageous for Wisconsin free banks than for other purchasers. For purposes of issuing notes, the bonds were valued at par: the banks could issue $\$ 100$ in notes after acquiring $\$ 100$ par value of bonds in return for $\$ 70$ on the purchase date. Despite this fractional backing, the banks resumed specie payments on December 1, 1861 and there is no evidence that banks received a financial subsidy from the state of Wisconsin due to these bonds.

\section{ESTIMATES OF SUSPENSION'S EFFECT}

Overall, the historical record indicates two major differences between Illinois and Wisconsin. In addition to the suspension in Wisconsin but not Illinois, banks in Illinois were more highly leveraged, had more notes outstanding, and the consequent higher losses relative to capital in Illinois may account for Illinois' higher failure rate. The purpose of this section is to present statistical evidence on the effects of the suspension of payments on the number of banks that closed and on noteholders' losses. We do this by comparing outcomes in Illinois and Wisconsin, controlling for other possibly important differences between the two states. 


\section{The Analytical Setup}

A systematic way of thinking about the suspension of payments is a two-equation system for banks closing and noteholders' losses during this episode. We set this up as a two-equation system in latent variables for banks open in October 1860 in Illinois and January 1861 in Wisconsin. The variables are: the present value of bank's earnings twelve months later if it is open or as of its closing date; and the value of the bank's notes twelve months later or when it closes. The equation for bank $i$ 's present value of earnings, $b_{i}$, is

$$
b_{i}=\beta^{b^{\prime}} \mathbf{x}_{i}^{b}+\varepsilon_{i}^{b}, \quad b_{i} \in(-\infty, \infty)
$$

where $\beta^{b}$ is a column vector of coefficients, $\mathbf{x}_{i}^{b}$ is a vector of variables exogenous to the bank that affect its present value, and $\varepsilon_{i}^{b}$ is an error term that we assume to be normally distributed. The equation for the value of bank i's notes, $n_{i}$, is

$$
n_{i}=\beta^{n^{\prime}} \mathbf{x}_{i}^{n}+\varepsilon_{i}^{n}, \quad n_{i} \in[0, \infty)
$$

where $\beta^{n}$ is a vector of coefficients, $\mathbf{x}_{i}^{n}$ is a vector of variables exogenous to the bank that affect the value of a bank's notes and $\varepsilon_{i}^{n}$ is an error term with a truncated normal distribution. The value of the notes is strictly non-negative because noteholders' losses are limited to the value of the notes.

Friedman and Schwartz's conjecture (1963) and Wallace's (1990) and Gorton and Huang's (2002) analyses suggest that the suspension resulted in fewer banks closing. If so, other things the same, relatively fewer banks closed in Wisconsin than in Illinois. Suspension also can decrease noteholders' losses. This reduction in noteholders' losses can occur because the assets of closing banks are sold at relatively low prices, because recapitalization of a bank is cheaper with a suspension, because joint guarantees such as are reported for Wisconsin in 1861 are valuable and 
feasible with a suspension, or possibly for other reasons. We include a dummy variable in equations (1) and (2) that equals one for the state with a suspension, Wisconsin, and zero for Illinois.

Losses relative to a bank's capital affect the bank's present value. In a simple extension of Wallace's (1990) model, it is not hard to show that owners' capital in the bank is important for determining whether or not a bank will close as a result of a run. More generally, if a bank wishes to remain open and the value of its bonds has fallen, the bank must buy additional bonds or redeem some of the notes and withdraw them from circulation. It can finance this either by reducing its other assets or by raising additional equity capital. If the losses are large enough, the bank's owners can increase their wealth by discontinuing operations, leaving the noteholders with the losses and possibly starting another bank or business. ${ }^{14}$ This does not mean that a bank necessarily will close if it has a negative book value of equity capital. The bank may have acquired reputational capital that the owners will forfeit along with the bank's charter, and noteholders' losses in previous banks are likely to increase the owners' cost of starting a bank even at a different location.

While losses relative to capital affect the decision about whether or not a bank remains open, losses relative to notes directly affect noteholders' receipts in the event of liquidation of the bank and therefore the notes' value. Losses relative to capital are important only insofar as they affect the probability that a bank will remain open. Hence, we include losses relative to notes in the equation for the notes' value.

Balance-sheet values and ratios may be relevant measures of the susceptibility of a bank to a run or of ex ante riskiness. For example, a bank's bonds relative to capital may measure the

\footnotetext{
${ }^{14}$ Shareholders' double liability would affect these computations, but there is not enough evidence about its enforcement to make it possible to estimate the frequency of judgements or collections.
} 
exposure of a bank to losses on its bond portfolio that are not captured by our estimate of ex post losses. We calculate each bank's losses based on changes in bond prices from July 1860 to July 1861 and its portfolio prior to the decrease in bond prices, which may not completely reflect the bank's exposure. ${ }^{15}$ In addition, the ratio of notes to assets indicates the exposure of a bank to a run on its notes. A ratio close to zero suggests that a run on the bank's notes would have little effect, and a ratio approaching one suggests that such a run on notes would be more likely to be devastating. As a result, we estimated an equation with the logarithms of all four variables - notes, bonds, capital and assets - and tested for coefficients being zero or being equal in magnitude. This procedure indicates that the ratio of bonds to capital and the ratio of notes to assets fit the data as well as the unrestricted combination of these balance-sheet items. ${ }^{16}$ The estimated effect of suspension is invariant to any alternative specification of these variables.

Because the age of a bank can affect both its present value and the value of its notes, we include the age of a bank in both estimated equations. Increases in age can be associated with an increase in a bank's present value if age is positively related to a bank's reputation for reliably redeeming its notes, as Gorton's (1996) evidence indicates. The existence of wildcatting, starting a bank to earn positive returns by issuing notes with only transitory operation and redemption, also could account for such an association, but it is not necessary for an association between a bank's present value and its age.

\footnotetext{
15 The details of the computations are in a Data Appendix available from the authors.

${ }^{16}$ The Chi-square for reducing the set of estimated coefficients by 4 is 1.2406 with a p-value of 0.871 . We did not distort the relationship to have a simple test. The fit is worse with the values of these four balance-sheet items instead of their logarithms.
} 
In both equations, we also include the population density for the county in which a bank is located. Wildcatting is alleged to be associated with lower population density. If this is so, or if noteholders commonly believed this, then higher population density is associated with a lower probability of a bank closing and a higher value of its notes.

\section{The Likelihood Function}

The data are whether a bank remains open or closes and the bank's redemption rate. We interpret these as indicator variables for the latent variables in (1) and (2). An open bank with a redemption rate less than one is illegal and therefore not observed in the data. A bank closing can have a redemption rate of one as well as a redemption rate less than one. Hence, the latent variables and the indicators are dependent. This situation is related to the model of partial observability introduced by Poirier (1980). Independent estimation of equations (1) and (2) is inefficient and the usual estimator of (2) is inconsistent (Poirier 1980; Maddala 1983; Meng and Schmidt 1985). We estimate equations (1) and (2) simultaneously by maximum likelihood, which will have the usual desirable properties.

We do not know the present value of a bank's earnings, but we do know whether a bank remained open. The indicator dvopen is equal to one if a bank remains open and zero otherwise. We assume that this indicator is related to the latent variable, the bank's present value, by

$$
\text { dvopen }_{i}=\left\{\begin{array}{l}
1 \text { if } b_{i} \in[0, \infty) \\
0 \text { if } b_{i} \in(-\infty, 0)
\end{array}\right.
$$

The discreteness of the information available about the latent variable implies that, in a single equation setup, a probit estimator would be appropriate. 
The redemption rate paid to noteholders is an indicator of the value of the bank's notes. ${ }^{17}$ The redemption rate is truncated at zero, as is the value of the bank's notes. The observed redemption rate also is limited above at one. If the value of the bank's bond account exceeds the value of the notes, the laws require that bank's stockholders receive the excess. Hence, the average value of the notes could be above one, and we interpret the value of the notes, $n_{i}$, as that average value. This implies that the distribution of observed note values, which are the marginal value of the notes to noteholders at the bank when a bank is open and the average received by noteholders when the bank closes, is censored at one. This censoring at one is important in the sense that many of the redemption rates are at this limit point. In sum, the redemption rate, $r_{i}$, is related to the value of the notes by

$$
r_{i}=\left\{\begin{array}{c}
1 \text { if } n_{i} \in[1, \infty) \\
n_{i} \text { if } n_{i} \in[0,1)
\end{array}\right.
$$

which implies that an estimator with truncation from below and censoring at one is appropriate.

We assume that the underlying distribution of a bank's present value and the value of its notes has a truncated bivariate normal distribution. Denote the joint distribution of bank $i$ 's present value and the value of its notes by

$$
\mathrm{f}^{\mathrm{t}}\left(b_{i}, n_{i}\right), \quad b_{i} \in(-\infty, \infty), \quad n_{i} \in[0, \infty)
$$

\footnotetext{
${ }^{17}$ Because we do not have information about legal proceedings after banks closed, we ignore shareholders' liability for capital subscribed but not paid in and shareholders' double liability for closed banks. Also, we do not have information to calculate the present value of the noteholders' receipts.
} 
where $\mathrm{f}^{\mathrm{t}}(.,$.$) denotes a truncated bivariate normal probability distribution function (pdf). The notes'$ value is truncated at zero. For the normal distribution, this pdf is related to the bivariate normal pdf by

$$
\mathrm{f}^{\mathrm{t}}(b, n)=\sigma_{b}^{-1} \sigma_{n}^{-1} f\left(z^{b}, z^{n}\right) /\left[1-\Phi\left(-\beta^{n^{\prime}} \mathbf{x}^{n} / \sigma_{n}\right],\right.
$$

where we suppress the subscript $i$ and define $z^{b}=\left(b-\beta^{b^{\prime}} \mathbf{x}^{b}\right) / \sigma_{b}$ and $z^{n}=\left(n-\beta^{n^{\prime}} \mathbf{x}^{n}\right) / \sigma_{n}$, $\mathrm{f}\left(z^{b}, z^{n}\right)$ is the bivariate standard normal pdf and $\Phi\left(-\beta^{b^{\prime}} \mathbf{x}^{n} / \sigma_{n}\right)$ is the standardized normal cumulative distribution function (cdf) evaluated from - - to $-\beta^{b^{\prime}} \mathbf{x}^{n}$. Capital letters denote cdfs and lower case letters denote pdfs. Because only the sign of the bank's present value is observable, $\sigma_{b}$ is not identifiable and can be normalized to one. In addition, because $1-\Phi\left(-\beta^{n^{\prime}} \mathbf{x}^{n} / \sigma_{n}\right)=\Phi\left(\beta^{n^{\prime}} \mathbf{x}^{n} / \sigma_{n}\right)$ for the normal (and any symmetric) distribution, equation (6) can be simplified to

$$
\mathrm{f}^{\mathrm{t}}(b, n)=k \mathrm{f}\left(z^{b}, z^{n}\right)
$$

where $k=\left[\sigma_{n} \Phi\left(\beta^{n^{\prime}} \mathbf{x}^{n} / \sigma_{n}\right)\right]^{-1}$. This is the underlying joint distribution of a bank's present value and the value of its notes for all banks.

The computation of the likelihood of observations can be summarized fairly simply. If a bank remains open, its present value is nonnegative and the value of its notes is greater than or equal to one. Hence, the likelihood of such an observation is

$$
\int_{0}^{\infty} \int_{1}^{\infty} \mathrm{f}^{\mathrm{t}}(b, n) d n d b=k\left[1-\Phi\left(z^{b}\right)-\Phi\left(z^{n}\right)+\mathrm{F}\left(z^{b}, z^{n}\right)\right],
$$


The values of $z^{b}$ and $z^{n}$ for evaluating the integrals are $z^{b}=\beta^{b^{\prime}} \mathbf{x}^{b}$ and $z^{n}=\left(1-\beta^{n^{\prime}} \mathbf{x}^{n}\right) / \sigma_{n}$. If a bank ceases operations, its present value is negative and the value of its notes is greater than or equal to one. The likelihood of such an observation is

$$
\int_{-\infty}^{0} \int_{1}^{\infty} \mathrm{f}^{\mathrm{t}}(b, n) d n d b=k\left[\Phi\left(z^{b}\right)-\mathrm{F}\left(z^{b}, z^{n}\right)\right]
$$

The values of $z^{b}$ and $z^{n}$ for evaluating the integrals in equation (9) are $z^{b}=-\beta^{b^{\prime}} \mathbf{x}^{b}$ and $z^{n}=\left(1-\beta^{n^{\prime}} \mathbf{x}^{n}\right) / \sigma_{n}$. If a bank fails, its present value is negative and the redemption rate is between zero and one. There is a useful computational simplification. For a particular value of the notes, $n_{0}$, the joint distribution of a bank's present value and its notes can be written as the product of the distribution of the present value conditional on the notes' actual value and the marginal distribution of the notes' value. The likelihood of such an observation then is

$$
\int_{-\infty}^{0} \mathrm{f}^{\mathrm{t}}\left(b, n_{0}\right) d b=k \sigma_{n}^{-1} \phi\left(z^{n}\right) \Phi\left(z^{u}\right)
$$

Here, $z^{n}=\left(n_{0}-\beta^{n^{\prime}} \mathbf{x}^{n}\right) / \sigma_{n}, z^{u}=\left(-\beta^{b^{\prime}} \mathbf{x}^{b}-\rho z^{n}\right)\left(1-\rho^{2}\right)^{-\frac{1}{2}}$, and $\rho$ is the correlation of the error terms in the two equations.

\section{The Estimates}

Table 6 presents equations estimated for the banks in Illinois and Wisconsin. The table presents the estimated coefficients and their standard errors, the latter calculated from the square root of the diagonal elements of the inverted Hessian. The table also presents the p-values of the likelihood ratio tests of the hypothesis that each coefficient is zero and the marginal effects of a change in each variable. The marginal probabilities in the present-value equation and the marginal 
effects in the note-value equation are the partial derivatives of the estimated equations evaluated at the means of the right-hand-side variables. ${ }^{18}$ The equation in the table for the bank's present value includes the logarithm of the bank's loss relative to capital because the logarithm fits better than the variable included linearly. The bank's age is included in the equations as a dummy variable that is zero unless a bank that is one year old or less in October 1861 in Illinois or in January 1862 in Wisconsin. This measure of age fits marginally better than age itself, the logarithm of age or a dummy variable for shorter or longer periods of operation. The table also presents estimates of the correlation of the errors across equations and the standard deviation of the error term in the note equation in addition to the likelihood ratio statistic to test whether all coefficients other than the intercepts are zero. ${ }^{19}$

Overall, we conclude that the estimated equations fit relatively well. In the two equations combined, the likelihood ratio test statistic of 185.42 with 12 degrees of freedom is quite statistically significant. In each equation, the sets of coefficients of right-hand-side variables are quite statistically significant. Table 7 presents the predicted and actual outcomes from each equation for the banks. For this table, a bank is predicted to stay open if the estimated probability that it will remain open is 50 percent or more; otherwise it is predicted to close. A bank is predicted to have notes redeemed at par if the predicted value of its notes is one dollar per dollar of notes or more. The predictions of which banks close, banks that cease operations and pay par value to noteholders, are

\footnotetext{
${ }^{18}$ The value of notes, losses relative to notes and losses relative to capital are all measured in dollars per dollar. The population density is measured as persons per acre.

${ }^{19}$ We also estimated equations that included an additional variable used in our previous paper (Hasan and Dwyer 1994), the fraction of other banks in the county that closed. The coefficients for this variable are a fraction of their standard deviations and the chi-square for both coefficients is 0.04 with a p-value of .98 .
} 
particularly poor. Apparently, basing a prediction that a bank will close based on these equations, a probability of staying open less than 50 percent, and a point forecast of par or more for the notes is not a good rule. A 50 percent probability to separate outcomes is conventional and a forecast of par redemption when the equation forecasts par redemption or better is plausible but not inevitable. A closer match of predictions and outcomes would result from an adjustment of these rules to generate forecasts. We do not pursue this line of inquiry. The results in the table are enough to evaluate the forecasts, especially because it is a matter of judgement whether the forecasts confirm the value of the estimates or not. We conclude that the equations can discriminate between banks reasonably successfully.

With one exception, all of the estimated signs of statistically significant coefficients are those we expected. The exception is the coefficient of the logarithm over bonds capital. If this coefficient reflected exposure to the fall in bond prices, the estimated coefficient would be negative. Instead, it is positive in both equations and the p-values are $1.74 \times 10^{-4}$ and 2.7 percent. One possibility is that the ratio of a bank's bonds to capital is not exogenous to the bank and these positive signs reflect an underlying positive relationship between a bank's note issue and its present value and note value. Given the restriction on note issue in Wisconsin, this is quite plausible. None of our conclusions is affected and even the point estimates are little affected by including the logarithm of notes to capital, though, so we continue analyzing the estimates in Table 6.

The results confirm the importance of the decreases in bond prices. At any usual significance level, the results are inconsistent with ignoring losses on bonds. Because one bank had no losses on bonds, the variable in the bank present-value equation is the logarithm of one plus the ratio of bond losses to capital. To a first-order approximation, the computed marginal probability is the partial 
derivative of the probability of remaining open with respect to bond losses relative to capital. As the table indicates, an increase in bond losses relative to capital by one percentage point decreases the probability of remaining open by 0.88 percentage points. The note-value equation also reveals a large effect of bond losses. An increase in bond losses relative to notes by one percentage point decreases the expected value of notes by 0.98 percentage points and decreases the expected amount received by noteholders by 1.37 percentage points. At first glance, it seems strange that noteholders' expected value of notes falls by more than the expected value. The bond losses do, however, decrease the expected value of the notes in the obvious way. Noteholders' expected value falls more because their return is censored at one and they receive less than par when the note value is below par.

The estimated coefficients of a bank's age and population density can, but need not necessarily, be interpreted as reflecting wildcatting. If the coefficients reflect wildcatting, we conclude that they provide only weak support for the importance of wildcatting. The age of the bank is measured by a dummy variable to distinguish between relatively new banks and older ones. In neither equation is the variable statistically significant and it is not statistically significant in the two equations jointly. The p-value for the coefficients in both equations is only 72.6 percent. In addition, the sizes of the estimated effects of being a relatively new bank are not large. Evaluated at the means of the other variables, the probability that a bank not yet a year old will remain open is only 1.8 percent less than for older banks. The value of notes issued by a bank not yet a year old is 6.3 percent less. For comparison, Gorton estimates a much smaller additional discount of 0.8 percent 
for new banks relative to all free banks from 1851 to 1858 (Gorton 1996, p. 368.) ${ }^{20}$ Our estimate may be too imprecise to conclude with confidence that holders of relatively new banks' notes were more likely to have larger losses in 1861 .

The point estimates of the coefficients for population density are positive, but population density appears to be more important for the value of notes than for the probability of staying open. The p-value for the coefficient in the note-value equation is 0.9 percent. The mean population density for all banks is 0.11 persons per acre, with population density ranging from 0.05 to 0.55 persons per acre. Population density's interquartile range is from 0.07 to 0.10 persons per acre, a difference of 0.03 persons per acre. An increase in population density by 0.03 persons per acre increases the probability of a bank remaining open by 0.9 percent and increases the value of its notes by 2.3 percent. The effect on the probability of a bank remaining open seems relatively trivial, but the effect of population density on note value seems more than trivial to us.

As Table 6 indicates, both of the dummy variables for Wisconsin are individually quite statistically significant. In addition, the chi-square statistic with 2 degrees of freedom for the coefficients of both dummy variables is 21.36 , far greater than levels necessary for usual significance levels. In addition to being statistically significant, the estimated coefficients are substantial. Evaluated at the means of the variables, the equation implies that the probability that a bank will remain open is 11.5 percent in Illinois and 32.1 percent in Wisconsin. That is, evaluated

\footnotetext{
${ }^{20}$ Gorton (1996) defines a bank as new on its first appearance in Van Court's Counterfeit Detector and Bank Note List, which was printed monthly.
} 
at the means of the variables, the estimated equation implies that the probability that a bank will remain open is 21 percent higher in Wisconsin. ${ }^{21}$

This increase in the probability that banks will remain open is accompanied by a large change in the value of notes to noteholders. Table 6 reports the change in the expected value of notes with respect to the dummy variable, which equals zero for Illinois and one for Wisconsin. This change is calculated allowing for both the truncation and censoring of notes' values to noteholders. Hence, these effects are estimates of effects on the expected value received by noteholders. Evaluated at the means of the variables, the expected value of the notes is 84.4 cents on the dollar in Illinois and 98.8 cents in Wisconsin. The change in the estimated value of the notes is about 14 cents on the dollar. Put another way, relative to the par value of the notes, noteholders' expected loss is about 14.6 percent in Illinois and 1.2 percent in Wisconsin when evaluated at the means of other variables. From noteholders' perspective, this is a large difference in their expected losses.

We conclude that the suspension of payments is important. The historical record is consistent with the suspension being important and suggests few other relevant differences. The states are so similar that Illinois even passed a law to allow suspension, but the law was irrelevant because the law required that banks restore their bond accounts while bond prices were falling substantially. The historical record only suggests one possible difference that could account for the large difference between Illinois' and Wisconsin's experience: banks' greater note issues, leverage and losses relative to capital in Illinois. The estimated equations include leverage in addition to losses and note

\footnotetext{
${ }^{21}$ This estimated effect and the estimated effect on notes value are little different in any of the variants of the equations mentioned above.
} 
relative to assets as well as other variables suggested by relevant theories and the historical record. The estimated equations are quite consistent with the importance of the suspension.

\section{CONCLUSION}

In 1861, 44 percent of the banks in Wisconsin and 87 percent of the banks in Illinois closed. While these are very high numbers by any standard, an important aspect of the numbers is the disparity. The onset of the Civil War was associated with dramatic decreases in the value of southern states' bonds and substantial decreases in the value of these banks' assets. In the later National Banking period, banks responded to similar problems of lesser magnitude by suspending payments. These suspensions were extralegal: against the law but condoned by the Comptroller of the Currency. The effects of these suspensions and the purpose served by them are important issues for developing general theories of banking and for understanding the effects of central banking and deposit insurance. The contrast between Illinois and Wisconsin is an extraordinary case for examining the effects of suspensions. The major differences between the two states appear to be:

1. Illinois banks generally issued more notes and held less capital relative to their notes; and 2. Wisconsin banks had a suspension of payments.

The evidence indicates that the suspension of payments decreased the number of banks that closed. More banks would have closed in Illinois in any case because they had less capital. Nonetheless, with losses relative to capital held constant, our evidence indicates more than a 20 percent increase in the probability that an average bank in the two states will remain open. Noteholders' losses on their banknotes also are affected substantially: their expected losses fall about 15 percent. 
Our results indicate that a suspension of payments decreases noteholders' losses, a result consistent with Wallace's (1990) and Gorton and Huang's (2002) model of suspensions. Besides reducing noteholders' ultimate losses, a suspension of payments reduces the discounts taken by noteholders even relative to those ultimate losses. All of this is more consistent with Gorton and Huang's information-based theory than Wallace's sunspot theory.

Our evidence provides substantial support for Friedman and Schwartz's (1963) conjecture that a suspension of payments by banks in 1930, similar to those between the Civil War and the creation of the Federal Reserve, would have had a dramatic effect on the course of the Depression. Even though a suspension of payments is not a cure for a bad state of the world, our evidence indicates that the number of banks failing and depositors' losses would have been less. While our evidence clearly indicates that a suspension of payments can be beneficial for the nonbank public and banks' owners, it leaves the mechanism open. The data on bond prices are consistent with asset sales lowering the prices of the bonds, but southern bond prices would have fallen anyway. The evidence in Dwyer and Gilbert (1989) indicates that New York banks repeatedly increased reserves to relatively high levels during each suspension in the National Banking period. The relative importance of these and other possible responses to a run is an important question for future research because suspensions are an important part of banks' responses to banking panics and crises in the absence of an effective central bank. 


\section{References}

Aiyagari, S. Rao, and Mark Gertler. 1999. “Overreaction of Asset Prices in General Equilibrium.” Review of Economic Dynamics 2 (January), pp. 3-35.

Andersen, Theodore A. 1954. A Century of Banking in Wisconsin. Madison: State Historical Society of Wisconsin.

Banker's Magazine. Various issues.

Bernanke, Ben S. 1983. "Nonmonetary Effects of the Financial Crisis in Propagation of the Great Depression.” American Economic Review 73 (June): 257-76.

Brownlee, Richard S. 1958. Gray Ghosts of the Confederacy: Guerrilla Warfare in the West, 1861-1865. Louisiana State University Press.

Calomiris, Charles W., and Joseph R. Mason. 1997. “Contagion and Bank Failures during the Great Depression: The June 1932 Chicago Banking Panic.” American Economic Review 87 (December), 863-83.

Current, Richard N. The History of Wisconsin. 1976. Volume II, The Civil War Era, 1848-1873. Madison: State Historical Society of Wisconsin.

Diamond, Douglas W., and Phillip H. Dybvig. 1983. "Bank Runs, Deposit Insurance and Liquidity." Journal of Political Economy 91 (June): 401-19.

Dowd, Kevin. 1988. “Option Clauses and the Stability of a Laisser-faire Monetary System.” Journal of Financial Services Research 1: 319-33.

Dowrie, George William. 1913. The Development of Banking in Illinois, 1817-1863. Volume 11, No. 4 of the series, University of Illinois Studies in the Social Sciences, December 1913. Urbana: University of Illinois. 
Dwyer, Jr., Gerald P., and R. Alton Gilbert. 1989. "Bank Runs and Private Remedies.” Federal Reserve Bank of St. Louis Review 71 (May/June): 43-61.

Dwyer, Jr., Gerald P., R. W. Hafer and Warren E. Weber. 1999. "Weekly U.S. and State Bond Prices, 1855-1865." Historical Methods 32 (Winter): 37-42.

Economopoulos, Andrew. 1988. "Illinois Free Banking Experience.” Journal of Money, Credit and Banking 20 (May): 249-64.

Friedman, Milton, and Anna J. Schwartz. 1963. A Monetary History of the United States, 1867-1960. Princeton: Princeton University Press.

Gorton, Gary. 1988. “Banking Panics and Business Cycles.” Oxford Economic Papers 40: 751-81. . 1996. "Reputation Formation in Early Bank Note Markets." Journal of Political Economy 104 (April): 346-97.

, and Lixin Huang. 2002. "Bank Panics and the Endogeneity of Central Banks." NBER Working Paper 9102. , and Andrew Winton. 2002. "Financial Intermediation.” NBER Working Paper 8928.

Hadden, Clarence Bernard. 1895. History of Early Banking in Wisconsin. Madison, Wisconsin.

Hasan, Iftekhar, and Gerald P. Dwyer, Jr. 1994. "Bank Runs in the Free Banking Period.” Journal of Money, Credit and Banking 26 (May): 271-88.

Hunt's Merchants Magazine and Commercial Review. Various issues.

Illinois. 1861. Journal of the House of Representatives, Report of the Committee on Banks and Corporations, February 11, 1861. 22nd Assembly. Volume II, pp. 449-58.

Illinois. 1851-1861. Laws of Illinois. 
James, F. Cyril. 1938. The Growth of Chicago Banking. Volume I, The Formative Years, 1816-1896. New York: Harper and Brothers Publishers.

Krueger, Leonard. 1933. History of Commercial Banking in Wisconsin. Madison: University of Wisconsin.

Maddala, G. S. 1983. Limited-Dependent and Qualitative Variables in Econometrics. Cambridge: Cambridge University Press.

Meng, Chun-Lo, and Peter Schmidt. 1985. "On the Cost of Partial Observability in the Bivariate Probit Model.” International Economic Review 26 (February): 71-85.

Merk, Frederick. 1913. Economic History of Wisconsin During the Civil War Decade. Madison: Wisconsin Historical Society.

Poirier, Dale J. 1980. "Partial Observability in Bivariate Probit Models.” Journal of Econometrics 12 (February): 209-17.

Ratchford, B. U. 1941. American State Debts. Durham: Duke University Press.

Rockoff, Hugh. 1975. The Free Banking Era: A Reexamination. New York: Arno Press.

Rolnick, Arthur J. and Weber, Warren E. 1984. “The Causes of Free Bank Failures.” Journal of Monetary Economics 14 (October): 269-91.

Schwab, John Christopher. 1901. The Confederate States of America, 1861-1865, A Financial and Industrial History of the South during the Civil War.

Selgin, George A. 1993. "In Defense of Bank Suspension.” Journal of Financial Services Research 7 (December): 347-64.

Selgin, George A., and Lawrence H. White. 1994. "How Would the Invisible Hand Handle Money?" Journal of Economic Literature 32 (December): 1718-49. 
Wallace, Neil. 1990. "A Banking Model in Which Partial Suspension is Best.” Federal Reserve Bank of Minneapolis Quarterly Review 14 (Fall): 11-23.

Wisconsin. Laws of Wisconsin. 1861. 
Table 1

\section{Major Provisions of THE Free BANKING LAWS ILLINOIS AND WISCONSIN IN LATE 1860 AND EARLY 1861}

\begin{tabular}{|c|c|c|}
\hline RESTRICTION & ILLINOIS & WISCONSIN \\
\hline \multicolumn{3}{|l|}{ Backing for Banknotes } \\
\hline Eligible bonds & $\begin{array}{l}\text { U.S. and states paying full } \\
\text { interest }\end{array}$ & $\begin{array}{l}\text { U.S. and states paying full } \\
\text { interest. Also secured Wisconsin } \\
\text { railroad bonds with } 7 \text { percent } \\
\text { coupon, but not more than half of } \\
\text { a bank's total bond deposit. }\end{array}$ \\
\hline $\begin{array}{l}\text { Value of bonds used to } \\
\text { determine notes issues }\end{array}$ & $\begin{array}{l}\text { Ninety percent of the last } 6 \\
\text { months average price. Fifty } \\
\text { percent if coupon less than } 6 \\
\text { percent. Not more than par value } \\
\text { or market value at time of } \\
\text { deposit. }\end{array}$ & $\begin{array}{l}\text { The average of the last } 6 \text { months } \\
\text { price. Shall be, or be made equal } \\
\text { to, } 6 \text { percent coupon bonds. Not } \\
\text { more than par value or market } \\
\text { value at time of deposit. }\end{array}$ \\
\hline Other limits on notes issued & & $\begin{array}{l}\text { Total note issue not to exceed } \\
\text { subscribed capital. }\end{array}$ \\
\hline Bond account deficient when & $\begin{array}{l}\text { Bonds lessened in value or } \\
\text { insufficient as security. }\end{array}$ & $\begin{array}{l}\text { Market value of bonds for } 60 \\
\text { days less than value at which } \\
\text { deposited. }\end{array}$ \\
\hline $\begin{array}{l}\text { Grace period to make up } \\
\text { deficiency }\end{array}$ & $\begin{array}{l}\text { Reasonable time (in practice } \\
\text { before } 1861,40 \text { days). }\end{array}$ & 30 days \\
\hline \multicolumn{3}{|l|}{ Bank Capital } \\
\hline Minimum subscribed capital & $\$ 50,000$ & $\$ 25,000$ \\
\hline Minimum paid-in capital & $\$ 50,000$ & \\
\hline Maximum capital & & $\$ 500,000$ \\
\hline Stockholders' liability & Double subscribed capital & $\begin{array}{l}\text { Double subscribed capital plus } \\
\text { bond for value of one-quarter of } \\
\text { notes issued. }\end{array}$ \\
\hline $\begin{array}{l}\text { Liability after sale or transfer } \\
\text { of stock }\end{array}$ & 6 months & 6 months \\
\hline \multicolumn{3}{|l|}{ Protested Notes } \\
\hline Grace period to redeem & 10 days & 10 days \\
\hline $\begin{array}{l}\text { Penalty paid to holder of } \\
\text { protested notes }\end{array}$ & 12 percent per year & 5 percent damages \\
\hline Bank Statement Published & Quarterly & Semi-annually \\
\hline Population & $\begin{array}{l}\text { Cities, towns, or villages with at } \\
\text { least } 200 \text { population }\end{array}$ & $\begin{array}{l}\text { Cities, towns, or villages with at } \\
\text { least } 200 \text { voters }\end{array}$ \\
\hline
\end{tabular}

Sources: See Data Appendix. 


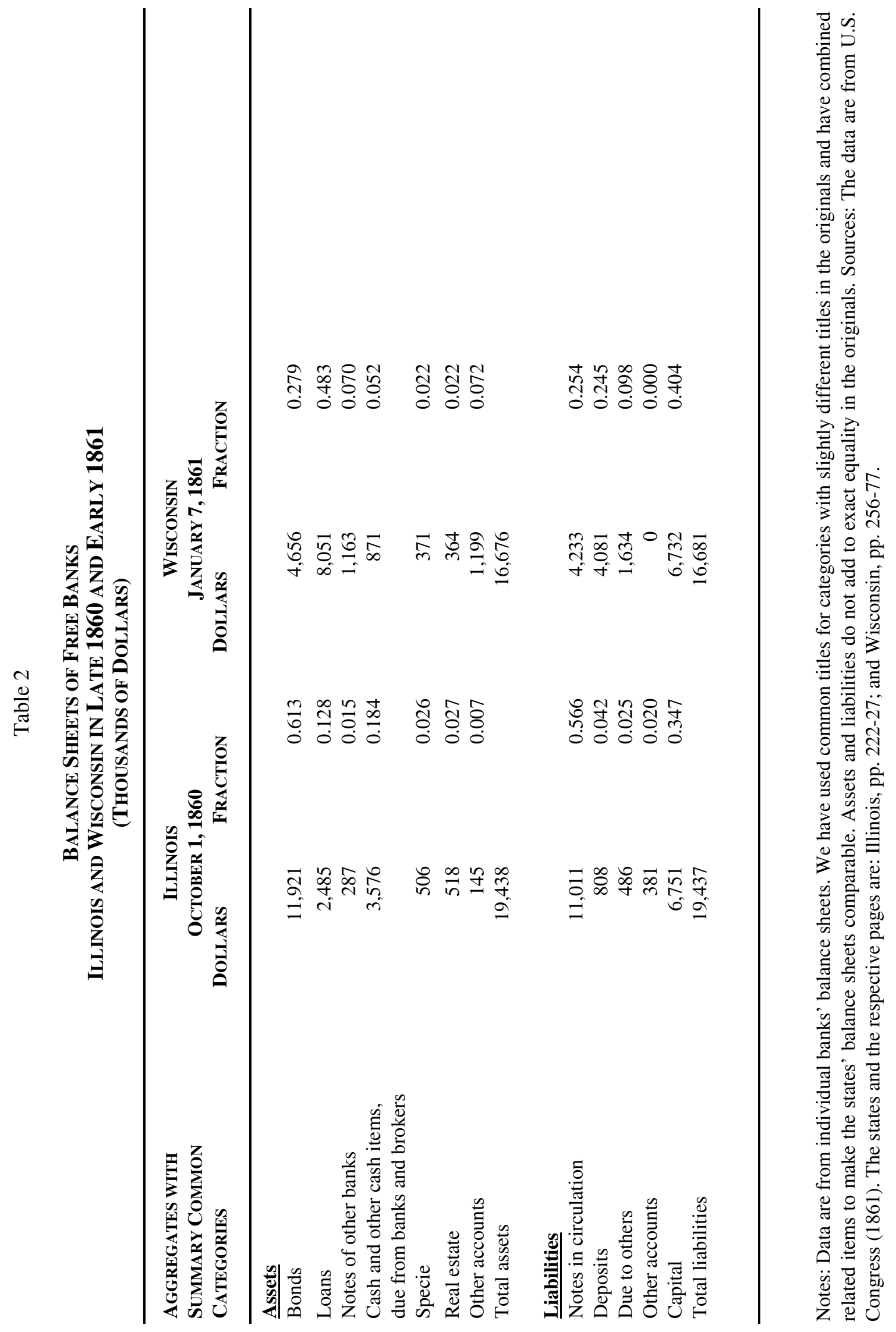


Table 3

BANKS ENTERING AND EXITING

ILLINOIS AND WISCONSIN FROM 1852 TO 1863

\begin{tabular}{|c|c|c|c|c|}
\hline YEAR & $\begin{array}{l}\text { NUMBER OF BANKS } \\
\text { (START OF YEAR) }\end{array}$ & OPENED & $\begin{array}{c}\text { CEASED } \\
\text { OPERATION }\end{array}$ & FAILED \\
\hline \multicolumn{5}{|c|}{ Illinois Free Banks } \\
\hline 1852 & - & 21 & - & - \\
\hline 1853 & 21 & 9 & 0 & 0 \\
\hline 1854 & 30 & 3 & 5 & 0 \\
\hline 1855 & 28 & 12 & 3 & 0 \\
\hline 1856 & 37 & 16 & 1 & 0 \\
\hline 1857 & 52 & 5 & 5 & 2 \\
\hline 1858 & 50 & 10 & 5 & 0 \\
\hline 1859 & 55 & 22 & 2 & 0 \\
\hline 1860 & 75 & 34 & 1 & 0 \\
\hline 1861 & 108 & 4 & 2 & 86 \\
\hline 1862 & 24 & 5 & 1 & 3 \\
\hline 1863 & 25 & & & \\
\hline \multicolumn{5}{|c|}{ Wisconsin Free Banks } \\
\hline 1852 & - & 2 & - & - \\
\hline 1853 & 2 & 8 & 0 & 0 \\
\hline 1854 & 10 & 14 & 0 & 0 \\
\hline 1855 & 24 & 10 & 4 & 0 \\
\hline 1856 & 30 & 17 & 2 & 0 \\
\hline 1857 & 45 & 26 & 3 & 0 \\
\hline 1858 & 68 & 34 & 3 & 0 \\
\hline 1859 & 99 & 16 & 8 & 0 \\
\hline 1860 & 107 & 7 & 5 & 1 \\
\hline 1861 & 108 & 2 & 12 & 35 \\
\hline 1862 & 63 & 0 & 3 & 1 \\
\hline 1863 & 59 & & & \\
\hline
\end{tabular}

Sources: See Data Appendix. 
Table 4

\section{Discount RATES ON NOTES \\ ILLINOIS AND WISCONSIN IN 1860 AND 1861}

\begin{tabular}{|c|c|c|c|c|c|c|}
\hline $\begin{array}{l}\text { DISCOUNT } \\
\text { RATE }\end{array}$ & $\begin{array}{c}\text { JANUARY } \\
1860 \\
\end{array}$ & $\begin{array}{l}\text { JUNE } \\
1860 \\
\end{array}$ & $\begin{array}{c}\text { JANUARY } \\
1861 \\
\end{array}$ & $\begin{array}{l}\text { JUNE } \\
1861 \\
\end{array}$ & $\begin{array}{c}\text { JANUAR } \\
\text { Y } 1862 \\
\end{array}$ & $\begin{array}{c}\text { NOTEHOLDERS' } \\
\text { LOSS RATE } \\
\end{array}$ \\
\hline \multicolumn{7}{|l|}{ Illinois } \\
\hline 2.25 & & 77 & & & & 15 \\
\hline 2.5 & & & & & & \\
\hline 3 & 71 & & & & & \\
\hline 5 & & 2 & 2 & & 7 & \\
\hline 10 & & & & & 1 & 3 \\
\hline 12 & & & 76 & & & \\
\hline 15 & & & & & 3 & 4 \\
\hline 20 & & & 13 & & & 6 \\
\hline 25 & & & & & 6 & 4 \\
\hline 26 & & & & & 1 & \\
\hline 30 & & & & & 4 & 7 \\
\hline 35 & & & & & 6 & 12 \\
\hline 40 & & & 8 & & 1 & 16 \\
\hline 50 & & & 1 & & 16 & 32 \\
\hline 55 & & & & & 4 & 1 \\
\hline 60 & & & & 100 & 11 & \\
\hline 65 & & & & & 39 & \\
\hline Missing & 29 & 21 & & & 1 & \\
\hline $\begin{array}{l}\text { Correlation with } \\
\text { noteholders' loss rate }\end{array}$ & NA & 0.160 & 0.251 & NA & 0.855 & \\
\hline \multicolumn{7}{|l|}{ Wisconsin } \\
\hline 2.25 & & 104 & & & & 73 \\
\hline 2.5 & & 1 & & & & \\
\hline 3 & 101 & & & & & \\
\hline 5 & & 2 & & & 73 & 1 \\
\hline 10 & & & & & & 2 \\
\hline 12 & & & 110 & & & \\
\hline 15 & & & & & & 1 \\
\hline 20 & & & & 67 & & 4 \\
\hline 25 & & & & & & 10 \\
\hline \multicolumn{7}{|l|}{26} \\
\hline 30 & & & & & & 5 \\
\hline 35 & & & & & & 5 \\
\hline 40 & & & & & 3 & 4 \\
\hline 50 & & & & & 13 & 4 \\
\hline 55 & & & & & 8 & 1 \\
\hline 60 & & & & 43 & 3 & \\
\hline 65 & & & & & 10 & \\
\hline Missing & 9 & 3 & & & & \\
\hline $\begin{array}{l}\text { Correlation with } \\
\text { noteholders' loss rate }\end{array}$ & NA & 0.064 & NA & 0.686 & 0.834 & \\
\hline
\end{tabular}


Table 5

BONDS BACKING Note CiRCUlation

ILLINOIS AND WISCONSIN: FALL 1860

\begin{tabular}{lrrrr}
\hline & \multicolumn{2}{c}{ ILLINOIS } & \multicolumn{2}{c}{ WISCONSIN } \\
\hline Southern and Border State Bonds & & & & \\
Missouri 6s & $\$ 3,026,000$ & $(21.64)$ & $\$ 1,408,000$ & $(28.16)$ \\
Tennessee 6s & $3,321,000$ & $(23.76)$ & 834,000 & $(16.68)$ \\
Virginia 6s & $1,284,000$ & $(9.18)$ & 188,000 & $(3.77)$ \\
Louisiana 6s & 507,000 & $(3.63)$ & 165,500 & $(3.31)$ \\
N. Carolina 6s & 888,000 & $(6.35)$ & 596,500 & $(11.93)$ \\
S. Carolina 6s & 100,000 & $(0.72)$ & 0 & $(0.00)$ \\
Mississippi & 0 & $(0.00)$ & 27,000 & $(0.54)$ \\
Georgia 6s & 335,000 & $(2.40)$ & 58,500 & $(1.17)$ \\
Kentucky 6s & 66,000 & $(0.47)$ & 23,000 & $(0.46)$ \\
\multicolumn{1}{c}{ Total Southern and Border } & & $(68.15)$ & & $(66.02)$ \\
\hline
\end{tabular}

\section{United States and Northern Bonds}

U.S. 5s \& $6 \mathrm{~s}$

Illinois

New York 6s

Minnesota 8s

Michigan $6 s \& 7 s$

Iowa $7 \mathrm{~s}$

Ohio 7s

Wisconsin

California

Indiana

Specie

Total U.S. and Northern

$\begin{array}{rr}846,900 & (6.06) \\ 2,272,857 & (16.26) \\ 282,000 & (2.02) \\ 140,000 & (1.00) \\ 492,000 & (3.52) \\ 91,000 & (0.65) \\ 284,854 & (2.04) \\ 0 & (0.00) \\ 0 & (0.00) \\ 0 & (0.00) \\ 42,861 & (0.31)\end{array}$

(31.85)

$\begin{array}{rr}0 & (0.00) \\ 508,280 & (10.17) \\ 0 & (0.00) \\ 73,000 & (1.46) \\ 205,500 & (4.11) \\ 18,000 & (0.36) \\ 175,000 & (3.50) \\ 150,000 & (3.00) \\ 334,000 & (6.68) \\ 86,700 & (1.73) \\ 148,429 & (2.97)\end{array}$

\section{Total}

$\$ 13,979,973$

(100.00)

$\$ 5,000,009$

(100.00)

Sources: U.S. House Document 77, 36th Congress, 2nd session, 1861. The Illinois Bank Commissioner's Report of January 1861, which includes statements of condition as of October 1860. The Wisconsin Bank Comptroller of Banking's Report, which includes statements of condition as of September 30, 1860. 
Table 6

\section{ESTIMATED EQUATIONS \\ BANKS CLOSING AND REDEMPTION RATE \\ ILLINOIS AND WISCONSIN 1861}

\begin{tabular}{|c|c|c|c|c|}
\hline \multicolumn{3}{|c|}{ Bank PRESEnt VAlue } & \multicolumn{2}{|c|}{ Note VAlue } \\
\hline RIGHT-HAND-SIDE VARIABLES & $\begin{array}{l}\text { COEFFICIENT } \\
\text { STD. DeV. }\end{array}$ & $\begin{array}{c}\text { MARGiNAL } \\
\text { PrOBABILITY } \\
\text { P-VALUE }\end{array}$ & $\begin{array}{l}\text { COEFFICIENT } \\
\text { STD. DEV. }\end{array}$ & $\begin{array}{c}\text { MARGINAL EFFECT }^{A} \\
\text { P-VALUE }\end{array}$ \\
\hline Intercept & $\begin{array}{r}-1.875 \\
0.604\end{array}$ & .002 & $\begin{array}{l}0.815 \\
0.086\end{array}$ & $<10^{-3}$ \\
\hline $\begin{array}{l}\text { Dummy variable for } \\
\text { Wisconsin }\end{array}$ & $\begin{array}{l}0.844 \\
0.295\end{array}$ & $\begin{array}{r}0.291 \\
.004\end{array}$ & $\begin{array}{l}0.161 \\
0.036\end{array}$ & $\begin{array}{l}0.144 \\
<10^{-3}\end{array}$ \\
\hline Logarithm of loss/capital & $\begin{array}{r}-4.333 \\
1.168\end{array}$ & $\begin{aligned}-0.881 \\
<10^{-3}\end{aligned}$ & & \\
\hline Loss/notes & & & $\begin{array}{r}-0.975 \\
0.111\end{array}$ & $\begin{array}{r}-1.707 \\
<10^{-3}\end{array}$ \\
\hline Logarithm of bonds/capital & $\begin{array}{l}2.166 \\
0.549\end{array}$ & $\begin{array}{l}0.115 \\
<10^{-3}\end{array}$ & $\begin{array}{l}0.103 \\
0.046\end{array}$ & $\begin{array}{r}0.180 \\
.027\end{array}$ \\
\hline Logarithm of notes/assets & $\begin{array}{l}-1.975 \\
0.481\end{array}$ & $\begin{array}{r}-0.595 \\
<10^{-3}\end{array}$ & $\begin{array}{r}-0.384 \\
0.672\end{array}$ & $\begin{array}{l}-0.673 \\
<10^{-3}\end{array}$ \\
\hline $\begin{array}{l}\text { Dummy variable for age not } \\
\text { more than } 1 \text { year }\end{array}$ & $\begin{array}{l}0.227 \\
0.289\end{array}$ & $\begin{array}{r}0.070 \\
.433\end{array}$ & $\begin{array}{l}0.014 \\
0.030\end{array}$ & $\begin{array}{r}0.011 \\
.654\end{array}$ \\
\hline Population density & $\begin{array}{l}0.946 \\
1.465\end{array}$ & $\begin{array}{r}0.285 \\
.518\end{array}$ & $\begin{array}{l}0.434 \\
0.281\end{array}$ & $\begin{array}{r}0.760 \\
.122\end{array}$ \\
\hline Standard deviation of error & 1 & & 0.168 & \\
\hline $\begin{array}{l}\text { Correlation of errors } \\
\text { Likelihood ratio p-value }\end{array}$ & $\begin{array}{l}0.906 \\
<10^{-3}\end{array}$ & & & \\
\hline $\begin{array}{l}\text { Maximized value of log } \\
\text { likelihood }\end{array}$ & -44.915 & & & \\
\hline Number of observations & 198 & & & \\
\hline $\begin{array}{l}\text { Chi-square likelihood ratio } \\
\text { test statistic } \\
\text { Degrees of freedom } \\
\text { p-value }\end{array}$ & $\begin{array}{c}12 \\
<10^{-3}\end{array}$ & & & \\
\hline
\end{tabular}

a. For dummy variables, estimated effects of discrete changes from zero to one are shown instead of meaningless partial derivatives. 
Table 7

PREDICTIONS OF BANKS Closing AND REDEMPTION RATES

Predicted Number of BANKS

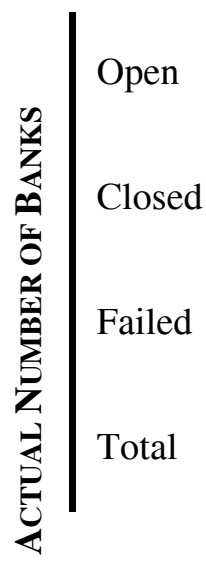

\begin{tabular}{|cccc}
\hline Open & Closed & Failed & Total \\
\hline 39 & 7 & 20 & 66 \\
7 & 4 & 7 & 18 \\
3 & 6 & 106 & 114 \\
49 & 17 & 132 & 198
\end{tabular}




\section{Figure 1 \\ Prices of Bonds}

December 3, 1858 to January 1, 1863

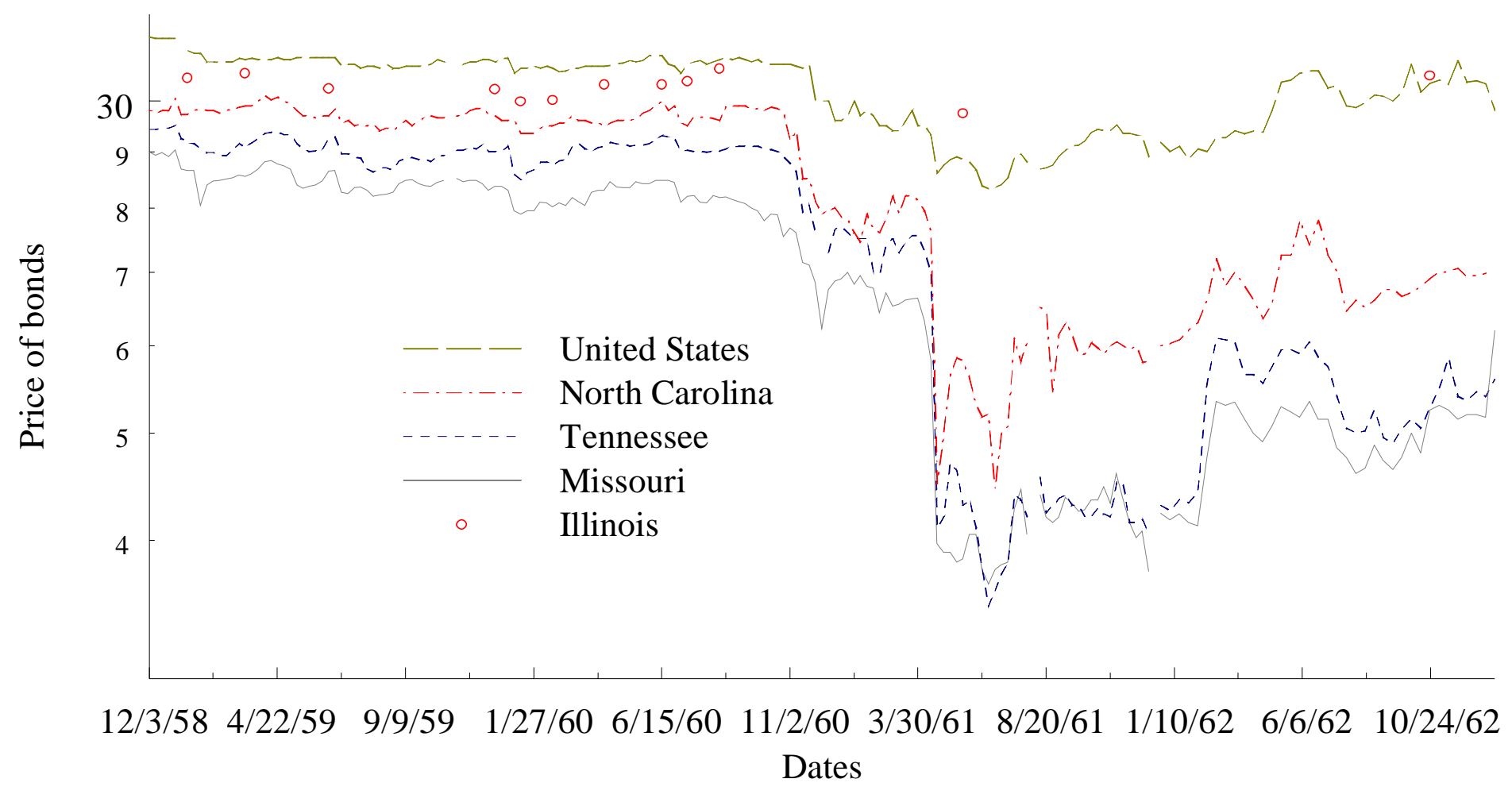


Figure 2

Banks Closing and Losses Relative to Capital in 1861

Illinois*
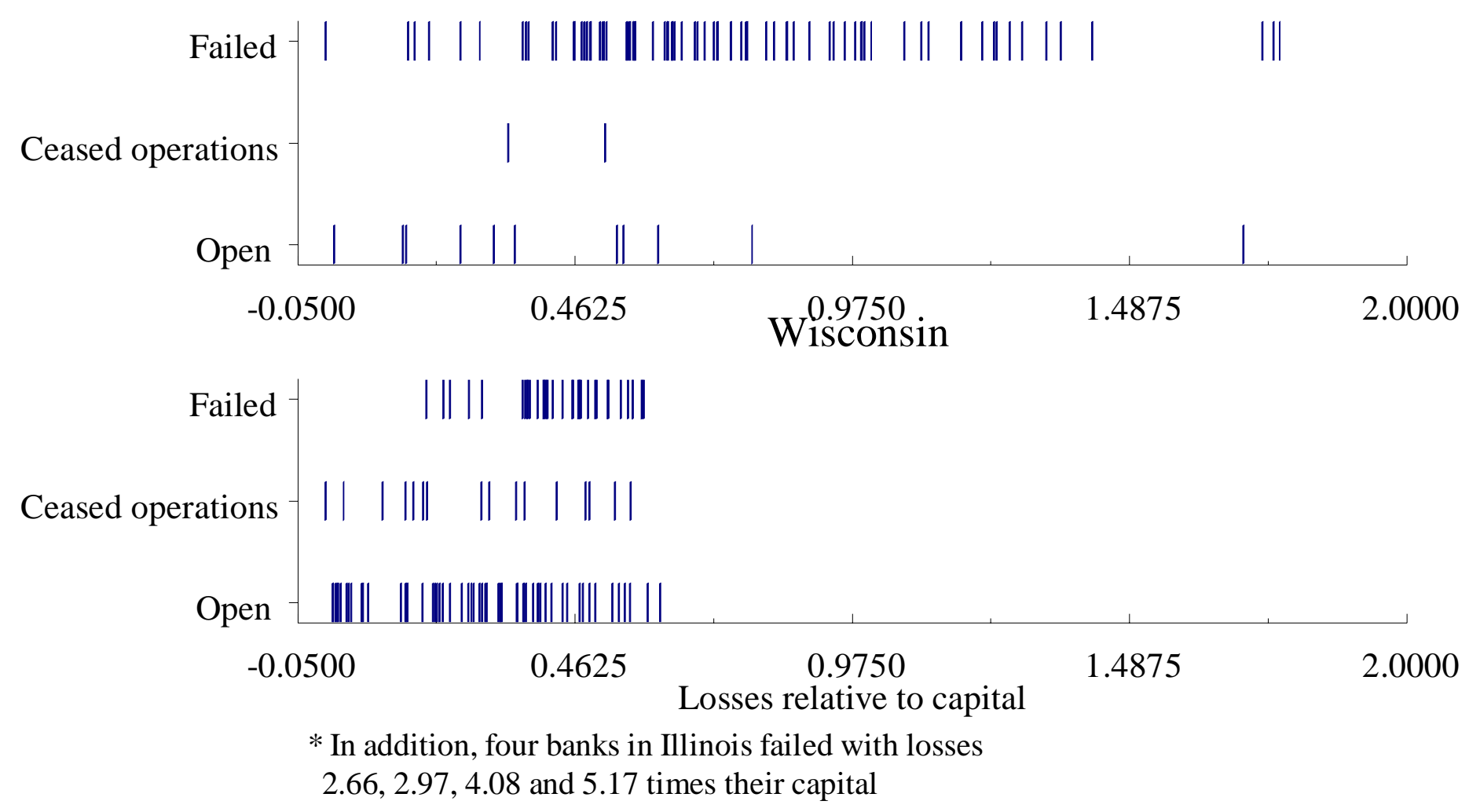


\section{DATA APPENDIX}

\section{ILLINOIS}

Free Banking Laws

The primary sources are Laws of Illinois, 1851, pp. 163-75; Laws of Illinois, 1857, pp. 23-25; Laws of Illinois, 1857, pp. 220-21; Laws of Illinois, 1861, pp. 39-71. An additional source is: Illinois Journal of the House of Representatives, Report of the Committee on Banks and Corporations, February 11, 1861, pp. 449-58.

\section{Bank Activities From 1852 through 1863}

The sources are: U.S. Congress (1853, p. 320; 1854, pp. 161-67; 1855, pp. 232-53; 1858, pp. 260-76; 1859, pp. 290-93; 1861, pp. 214-48; and 1863, pp. 160-64); Annual Reports of Bank Commissioners of the State of Illinois; and Economopoulos (1988).

The data on the number of banks are based on an unpublished worksheet, based on the Auditors records, provided to us by Andrew Economopoulos.

We include a bank in our statistical analysis if it reports balance sheet information for October 1860. We conclude that the bank closed if it does not report balance sheet information for October 1861 or is reported to be closing.

\section{Bond Holdings Before the Civil War}

Data on individual banks' holdings of individual bonds are not available from published sources. The data on individual bank's holdings of bonds are from unpublished data collected by Andrew Economopoulos. He estimates the stocks by following the deposits and withdrawals of bonds over time. There is a nontrivial difference between the aggregate data on holdings of each bond by all banks for October 1860 (U.S. Congress 1861, p. 290) and the total of Economopoulos's estimates for that date. Economopoulos's estimates of each bank's bond deposit are quite different than the amounts on reports submitted to the Bank Commissioner and, without an adjustment, these estimates imply quite unlikely ratios of bonds to other assets for individual banks. We estimate the bonds held by each bank by applying Economopoulos's estimate of the fraction of each bank's bonds held in the various bonds with the Bank Commissioner's data on each bank's total holdings of bonds in October 1860.

\section{Aggregate Notes Issued and Deposits}

The data on aggregate notes issued and deposits are from U.S. Congress (38th Congress, $1 \mathrm{st}$ Session, House Executive Document 20, Table 2, p. 216.)

\section{Redemption Rates}

The redemption rates for banks in Illinois are from Economopoulos (1988, Table 2, Illinois Failed Free Banks, pp. 258-59.) 


\section{Discount Rates on Notes}

The discount rates on notes are from Thompson's Bank Note and Commercial Reporter, for January 14, 1860 and from Hodges' Journal of Finance and Bank Reporter for June 9, 1860, January 1861 (volume 12, number 1), June 26, 1861 and January 15, 1862.

\section{Counties in Which Banks Are Located}

The counties in which banks are located are determined from reports to the Bank Commissioner, the U.S. Census and banknote reporters. The Report of Bank Commissioners of the State of Illinois, January 11, 1861 published in the U.S. Congress (1861, pp. 214-29) gives the community in which banks are located if the community's name is not part of the bank's name. The 1860 Census (U.S. Department of the Interior, 1864, State of Illinois, Table No. 3, Population of Cities and Towns, pp. 533-43) gives the county in which many communities are located. In cases in which the community is not included in the 1860 Census, we use the county given in one or more banknote reporters. Unfortunately, the counties in which several banks are located still are unresolved by this procedure. The main reason is that the Census Office did not receive information on subdivisions of several relatively large counties with several banks. As a result, we use the similar information from the 1870 Census (U.S. Department of the Interior, 1872, Table III, Population of Civil Divisions less than Counties, State of Illinois pp. 108-21) to determine the county for these banks.

This procedure determines the counties for all banks except the Bank of Southern Illinois in Bolton, Illinois. The comparable table in the 1880 Census (U.S. Department of the Interior, 1883, Population of Civil Divisions less than Counties, Table III, Illinois, pp. 145-47) provides the county for some unincorporated towns and Bolton is included. On the other hand, Dowrie (1913, p. 149) indicates that, in 1857, Bolton is a town in Williamson County with one family. We do not know if the bank moved after the 1857 amendment to Illinois' free banking law required that a bank be in a town or village with at least 200 people, and if it did move, where. We put the Bank of Southern Illinois in Williamson County.

\section{Population}

The populations of counties in Illinois are from the 1860 Census (U.S. Department of the Interior, 1864, State of Illinois, Table No. 2, Population by Color and Condition, pp. 86-87).

\section{Historical Information on Illinois}

The most important sources for our analysis are: Illinois, Journal of the House of Representatives (1861); Illinois, Laws of Illinois, 1851-1861; Bankers' Magazine; Hunt's Merchants Magazine and Commercial Review; U.S. Comptroller of the Currency (1876, p. CXVIII.); Dowrie (1913, pp. 131-73); James (1938, Ch. VIII); Rockoff (1975, pp. 110-14); Economopoulos (1988, pp. 249-64.)

\section{WISCONSIN}

Free Banking Laws

The primary sources are: Laws of Wisconsin, 1852, Chapter 479, pp. 706-22; Laws of Wisconsin, 1855, Chapter 47, pp. 46-47; Laws of Wisconsin 1858, Chapter 98, pp. 115-19; Laws of 
Wisconsin, 1861, Chapter 242, pp. 269-75; Laws of Wisconsin, 1861, Chapter 308, p. 318. Additional sources are: Wisconsin Historical Records Survey Project (1942, pp. 9-17); Bank Comptroller Annual Reports to the Governor, 1853 and 1858.

Bank Activities From 1852 through 1863

The sources are: U.S. Congress (1854, pp. 183-87; 1855, pp. 232-45; 1856; 1857; 1861, pp. 249-55; and 1863, pp. 200-209); and Rolnick and Weber (1982; Appendix, 1983).

The data on the number of banks are based on an unpublished worksheet, based on the state reports in the House Executive Documents, provided by Arthur Rolnick and Warren Weber.

We include a bank in our statistical analysis if it reports balance sheet information for January 1861 . We conclude that the bank closed if it does not report balance sheet information for January 1862 or is reported to be closing.

Bond Holdings Before the Civil War

The distribution of state bond holdings before the Civil War is from the Annual Report of the Bank Comptroller of the State of Wisconsin for the fiscal year ending September 30, 1860 published in the U.S. Congress (1861, pp. 249-55, 278-302).

Aggregate Notes Issued and Deposits

The aggregate data on notes issued and deposits are from U.S. Congress (38th Congress, 1 st Session, House Executive Document 20, Table 2, p. 217).

\section{Redemption Rates}

The redemption rates for banks in Wisconsin are from an unpublished table provided by Warren Weber.

\section{Discount Rates on Notes}

The discount rates on notes are from Thompson's Bank Note and Commercial Reporter, for January 14, 1860 and from Hodges' Journal of Finance and Bank Reporter for June 9, 1860, January 1861 (volume 12, number 1), June 26, 1861 and January 15, 1862.

\section{Counties in Which Banks Are Located}

The counties in which banks are located are determined from reports to the Comptroller, the U.S. Census and banknote reporters. The Annual Report of the Bank Comptroller of the State of Wisconsin for the fiscal year ending September 30, 1860 published in the U.S. Congress (1861, pp. 249-55, 278-302) gives the community in which banks are located if the community's name is not part of the bank's name. The 1860 Census (U.S. Department of the Interior, 1864, State of Wisconsin, Table No. 3, Population of Cities and Towns, pp. 533-43) gives the county in which a community is located. In cases in which the community is not included in the 1860 Census, we use the county given in one or more banknote reporters. This procedure determines the county in which all but two banks are located. We assume that the community of New London in 1860 is located in 
Waupaca county in 1860 , as is the current town with that name. We also assume that the community of North Pepin in 1860 is north of Pepin in Pepin county.

\section{Population}

The populations in counties in Wisconsin are from the 1860 Census (U.S. Department of the Interior, 1864, State of Wisconsin, Table No. 2, Population by Color and Condition, p. 532).

\section{Historical Information on Wisconsin}

The most important sources for our analysis are: Banker's Magazine; Hunt's Merchants Magazine and Commercial Review; Wisconsin, Laws of Wisconsin (1861); Merk (1916, pp. 187-219); Krueger (1933, pp. 57-96); Wisconsin Historical Records Survey Project (1942, pp. 17-25); Andersen (1954); and Current (1976).

\section{BOND PRICES}

The data on bond prices constituting more than 10 percent of the banks' portfolio are from various issues of Bankers' Magazine. The data are summarized in Dwyer, Hafer and Weber (1999).

In conjunction with the data on individual bank's bond holdings, bond prices are used to calculate the banks' losses on their bond portfolios. The losses are calculated using changes in bond prices from June 15, 1860 to June 15, 1861 and information on bank bond holdings in October, 1860. The bond holdings in October 1860 precede Lincoln's election in November 1860 and the South's subsequent secession.

When available, we use the bond prices provided by Banker's Magazine for June 15, 1860 and June 15, 1861 in its regularly-published table of bond prices. Bankers' Magazine includes tables with weekly prices for some issues and we use these prices directly. The bonds and their coupons are: U.S. 1867-68, 6; U.S. 1874, 5; Ohio 1886, 6; Kentucky, 6; Indiana, 5; Pennsylvania, 5; Virginia, 6; Georgia, 6; California 1877, 7; North Carolina, 6; Missouri, 6; Louisiana, 6; Tennessee, 6.

The prices of issues other than those in the table are estimated.

First, banks hold some bonds with different coupons, e.g. Indiana $2.5 \mathrm{~s}$ as well as $5 \mathrm{~s}$. We estimate the price of the 2.5 percent bonds by estimating the ratio of the price of 2.5 percent coupon bonds to 5 percent coupon bonds at the yield of the 5 percent bonds. We proceed similarly for other northern states' bonds. We estimate similar ratios for southern bonds at the value of an index of southern bond prices. These values are little different than ratios of the coupons for the bonds with exception of the prices of Indiana $2.5 \mathrm{~s}$ and $5 \mathrm{~s}$. The ratio of the estimated price of $2.5 \mathrm{~s}$ to the price of $5 \mathrm{~s}$ in 1860 is 0.61 in 1860 and 0.58 in 1861.

For other bond prices, we estimate average bond yields for northern and southern bonds and use these yields to compute prices. We construct the average yields using bond prices from Bankers' Magazine for the date closest to the fifteenth of the month. We calculate average yields for 1859 through June 1862 for northern states and for southern states. Other than the Ohio bonds, we have no information about maturity. Our computations suppose that the bonds mature in 1874 . The 
northern index is based on Ohio, Indiana and Pennsylvania. (We do not include the prices of U.S. bonds because their prices fell relative to northern states' bonds at the onset of war.) The southern index is based on Virginia, Georgia, North Carolina, Louisiana and Tennessee. Our estimated yields for northern bonds are 5.58 percent for June 1860 and 7.57 percent for June 1861. The estimated yields for southern bonds are 6.37 percent for June 1860 and 16.32 percent for June 1861 .

We have no information on the yields of South Carolina or Wisconsin bonds. We assume that the prices of these 6 percent coupon bonds reflect the average yields of southern and northern bonds, respectively.

There is scattered information on some bonds' prices. Several bonds are available for selected months other than June 1860 and June 1861 from 1859 through June 1862. Bankers' Magazine presents information on additional bond prices for the month prior in its issues of: February, March, April and July 1859; January, February March, May, June, July, August, September, and October 1860; March, June, October and December 1861; and June 1862.

The estimated yields on New York 6s, 1872-75 (10 scattered months) are 1.04 percent less than the average yield for northern states' bonds for those months. For June 1860 and 1861, we use the average yield of northern bonds less 1.04 percent to estimate the price of these New York 6s.

The estimated yields on Michigan 6s (10 scattered months) and Illinois 6s (12 scattered months) are little different than the average yield of northern states' bonds. A price for Illinois $6 \mathrm{~s}$ is given for June 1860 and we use that price (which implies an estimated premium of .05 percent, effectively zero). For June 1861 for Illinois and for June 1860 and 1861 for Michigan, we estimate the price of 6 percent bonds based on the average yield on northern bonds.

The average yields on Iowa 7s and Minnesota 8s are well above the average northern yields for the few dates that they are available. Prices of Iowa $7 \mathrm{~s}$ are available for January, February and March 1859. Their average yield of about 6.47 percent is about 0.67 percent above the average yield of northern states' bonds for the same dates. Prices of Minnesota 8s are available for January 1859, March 1859, July 1859 and May 1862. Their average yield of about 7.93 percent is 1.88 percent above the average yield of northern states' bonds. (The difference is 2.16 percent in January 1859 and 2.18 percent in May 1862.) We assume that these average yield differentials apply in June 1860 and June 1861 and calculate implied prices of Iowa 7s and Minnesota 8s.

We have virtually no information on the prices of Illinois bonds other than prices of "Illinois 6s." The discussion of Illinois debt and the history of outstanding issues at the end of 1861 in Hunt's Merchants Magazine and Commercial Review (February 1862, pp. 220, 222) and Ratchford's (1941, pp. 117-18) brief history of Illinois debt in the period suggest no reason for differences in prices for Illinois New Internal Improvement Stock, Illinois Interest Stock, Illinois and Michigan Canal Bonds, etc. We assume that the prices of all of these bonds are the same.

There is a relatively small amount of railroad bonds in a few banks' portfolios. We use Macaulay's unadjusted railroad bond yields (Macaulay 1938, Table 10) to estimate prices for these 
bonds. We assume that, on June 15, 1860, and June 15, 1861, the yields on the Racine and Mississippi Railroad bonds and the Milwaukee and Watertown Railroad bonds are the same as Macaulay's unadjusted railroad bond yields for 1860 and 1861. We estimate prices for the bonds on the assumption that the bonds have 8 percent coupons paid semi-annually with 25 years to maturity in 1860 .

\section{THE WISCONSIN WAR LOAN: Details}

Besides allowing a suspension of payments, the state of Wisconsin issued bonds that were purchased by banks in Wisconsin. At the onset of the Civil War, states were expected to feed, house, clothe and pay recruits until they entered the federal military and get reimbursement later. A \$1 million war loan was authorized by the legislature for financing Wisconsin's war efforts and the state attempted to sell the bonds in New York. After finding out the terms available on the loan in New York, the state completed on June 25, 1861 an agreement with the Wisconsin Bankers Association for the free banks to acquire the loan. Rather than issue \$1 million in bonds in New York, the state of Wisconsin issued $\$ 800,000$ of bonds that were purchased by the free banks.

The terms of the purchase were below par. This is not surprising: the bonds' coupon rate was 6 percent per year and the market prices of United States and other northern states' debt with coupons of 6 percent per year were well below par. In the weeks from June through November 1861, the yields on United States 6 percents due in 1867-68 range from a high of about 9.0 percent in June to a low of about 7.0 percent in November. (Bond prices in Bankers' Magazine in this period are not quoted flat, without the prospective interest payment, and we have calculated yields as if the prices were flat. Hence, the higher prices towards the end of the year partly reflect the anticipated interest payment, and the yield of 7.0 percent is too low. We did a rough calculation to estimate the effect of the interest payment. If the undiscounted interest payment is removed from the price of U.S. bonds, the low yield in November increases from 7.0 percent to about 7.5 or 7.6 percent. The 7.0 percent is an underestimate of the correct yield in November and 7.5 percent is an overestimate.) In this period, Ohio bonds have lower yields than the other regularly-quoted northern state bonds: Indiana and Pennsylvania bonds. Even the yields on Ohio 6 percents due in 1886 range from a high of about 7.1 percent in June to a low of about 6.6 percent in November.

The yield on the war loan is somewhat higher than the yield on Ohio bonds and lower than the yield on United States bonds. The banks paid 70 percent of the par value immediately. Sixty percent of this payment was to be in coin or New York banknotes; up to 10 percent of the payment could be in current Wisconsin banknotes. The remaining 30 percent of the par value was to be paid in regular installments over the next 15 years from the semiannual coupon payments attached to the bonds. In sum, the coupon on the bonds was 4 percent of the bonds' par value for 15 years and, if the term to maturity was 30 years, the yield to maturity was about 7.2 percent per year. (We can find no definite statement of the term to maturity). There is no evidence that the bonds were non-price rationed, and the yield on the bonds of about 7.2 percent is not much higher than our estimated yields on Ohio bonds during this period and is lower than our estimated yields on United States bonds. 
One provision of the bonds made these bonds more advantageous for Wisconsin free banks than for other purchasers. For purposes of issuing notes, the bonds were valued at par: the banks could issue $\$ 100$ in notes after acquiring $\$ 100$ par value of bonds in return for $\$ 70$ on the purchase date. Despite this fractional backing, the banks resumed specie payments on December 1, 1861 and there is no evidence that banks received a financial subsidy from the state of Wisconsin due to these bonds.

\section{Additional References}

Hodges' Journal of Finance and Bank Reporter, June 9, 1860, January 1861 (volume 12, number 1), June 26, 1861 and January 15, 1862.

Annual Reports of Bank Commissioners of the State of Illinois, Seventeen to Twenty-second General Assembly of Illinois. Springfield, Bailhache and Baker, Lanphier and Walker, 1851-61.

Inventory of the Articles of the State Banking Department of Wisconsin, The Wisconsin Historical Records Survey Project, Madison, Wisconsin, 1942.

Macaulay, Frederick R. Some Theoretical Problems Suggested by the Movements of Interest Rates, Bond Yields and Stock Prices in the United States since 1856. New York: National Bureau of Economic Research, 1938.

Rolnick, Arthur J., and Warren E. Weber, "A Theory of Free Bank Failures: Tests and Implications," Staff Report 79, Federal Reserve Bank of Minneapolis, April 1982.

. "New Evidence on Free Banking." American Economic Review 73 (December 1983): 1080-91.

Thompson's Bank Note and Commercial Reporter, January 14, 1860.

U.S. Comptroller of the Currency. Annual Report. 1876.

U.S. Congress. House Executive Document 66, 32nd Congress, 2nd Session (1853).

. House Executive Document 102, 33rd Congress, 1st Session (1854).

. House Executive Document 82, 33rd Congress, 2nd Session (1855).

. House Executive Document 102, 34th Congress, 1st Session (1856).

. House Executive Document 87, 34th Congress, 3rd Session (1857).

. House Executive Document 107, 35th Congress, 1st Session (1858). 
. House Executive Document 112, 35th Congress, 2nd Session (1859).

. House Executive Document 49, 36th Congress, 1st Session (1860).

. House Executive Document 77, 36th Congress, 2nd Session (1861).

. House Executive Document 25, 37th Congress, 2nd Session (1861).

. House Executive Document 20, 38th Congress, 1st Session (1863).

U.S. Department of the Interior. Population of the United States in 1860. Washington: Government Printing Office, 1864.

. The Statistics of the Population of the United States. Ninth Census, Volume I. Washington: Government Printing Office, 1872.

. Statistics of the Population of the United States at the Tenth Census. Washington: Government Printing Office, 1883. 